\begin{tabular}{lll}
\hline & JSM (9) (1) \\
\hline
\end{tabular}

\title{
Utilizing Pragmatism Approach in Learning Jazz Guitar Reharmonization Technique using Malay Asli Song
}

\author{
Chamil Arkasa Nikko bin Mazlan ${ }^{\otimes 1}$ \\ Music and Performing Art Sultan Idris Education University, Tanjung Malim, Malaysia \\ Mohd. Hassan bin Abdullah ${ }^{\bowtie 2}$ \\ Music and Performing Art Sultan Idris Education University, Tanjung Malim, Malaysia
}

\section{Info Artikel}

Received February 2020

Approved March 2020

Published June 2020

\section{Keywords:}

Pragmatism,

reharmonization technique, malay asli song, jazz guitar
Abstract

Details of developing jazz guitar reharmonization learning book using Malay Asli song will not discuss here, however, this article divulges pragmatism approach that can be transcending in explaining logic between learning jazz guitar reharmonization techniques using Malay Asli Song. Although music is a universal language, traditional music and western music educators do not come to an agreement diffusing learning western music elements such in traditional music or vice versa. As a result, reharmonization technique only become known on western music repertoires. While traditional music practitioners presenting the same old repertoires, with deep-rooted dogmatic excuses to maintain what they called traditional authentic values. To conduct this study, relevant data on pragmatism was done through document analysis. The result show pragmatism approach can help music educators to reconceptualize teaching and learning traditional music using jazz reharmonization technique to recreate and innovate a new sound and contextual of learning jazz harmony, not just using on jazz standards repertoires, in making music theory beneficial to both traditional and modern music educators and students.

\footnotetext{
$\triangle$ Departement of Dance, Drama and Music UNNES Gunungpati,

Semarang 50229

Email : 1.jazzerlogy@gmail.com

2.mohd@fmsp.upsi.edu.my
} 


\section{INTRODUCING}

The aim of this article is to broaden up a range of ideas for music educators and students, from modern or traditional music to assimilate knowledge of music theory, especially jazz harmony, not just using popular music repertoires, but also traditional music repertoires. Music theory can offer a wide range of apparatus in changing one music to another breed of a new arrangement, using a technique termed as reharmonization. By definition, harmony is when two or more notes played simultaneously at the same time. After students have mastered rudiments in music theory, they will start learning harmony (Spies, 2015). The terms harmony associated in both classical music theory and jazz harmony. Unlike classical or popular music, jazz music extensively uses seventh chords and tension notes such as $9^{\text {th }}, 11^{\text {th }}$, and $13^{\text {th }}$. Nevertheless, jazz harmony vocabulary actually emerged from classical music in the era of common practice, adapting popular songs and reinventing using the shorter structure of musical form like 12,16 or 32 bars. Afterwards, jazz harmony vocabulary is widely used and became practices among jazz musician (Spitzer, 2015).

Unfortunately, this does not transpire among Malay Asli traditional music practitioners, there is little disagreement and debating on the issue of which version is the most authentic or original (Hashim, 2010, 1). Debating is common, but if we view music as the same entity, even traditional music shared the same element of music such as harmony, scale and improvisation. Malay Asli music is a piece of syncretic music that includes vocal, dance, theatre and instrumental music (Abdullah, 2004). As shown by several studies, the variation of singing style in Malay Asli music based on singer creativity and personal interpretation (Hashim, 2010; Ahmed \& Kechot, 2015; Ritawati, 2017). More specifically, variations in Malay Asli singing style are influent from the singer individual experiences and creativity, not from nationalities such as Malaysian style or Indonesian style (Ritawati, 2017, page 71).
In addition, traditional music lesson presence in a conventional way, conducted through oral tradition via observing, listening and playing (Shah, 2013) and knowledge of Malay Asli music conveyed without any formal education by self-taught traditional music practitioners (Arshad, 2015).

Furthermore, a minority of traditional music practitioners assuming that traditional music will lose their authentic values if combining with western music. For instance, an example of rigid narrow mind-sets, Ahmad (2004) giving the suggestion that to sustain and maintain the legacy of Malay music, vocal training class should only conduct by an expert in Malay phonology, not someone who is expert in English phonology. Moreover, Ahmad criticized, it is like a cursed if traditional music world uses English as their lingua franca in teaching vocal classes (page 9). Not just in traditional music learning, in a case of modern music, previous research also indicates that learning jazz music in Malaysia tertiary education level mostly based on instruction material using The Real Book for teaching and learning (Low, 2014). Hence, as a result, this justified the reason why students and instrumental music teachers most likely choose jazz standard repertoire to learn music theory such as harmony and reharmonization techniques rather than using traditional music repertoires. Thus, either traditional or modern music students and teachers realized that their practices of music lead to narrow scope and unconsciously fall into a default setting, an unknown and uncritically outdated setting of learning that affects the process and result on learning and teaching (Regelski \& Gates, 2009).

Moving toward the $21^{\text {st }}$ century, learning music should be more dynamic, flexible and democratic ways, not autocratic. Unfortunately, even though intercultural music has been introduced in music programmes, there are few music teachers contemplate that it is hard to find a parallel point between intercultural music and it is not relevant to execute (Cain, 2015). To change is to critically evaluate our practices and accept what we currently 
teach or learn as problematic, including our professional standard practices (Regelski \& Gates, 2009). Out of our curiosity, pragmatism has emerged a long time ago and referred as philosophy (Elkjaer \& Buch, 2015), but why this theoretical paradigm did not get much attention especially in the music education setting. This paper is an attempt to highlight the issue of adapting western music theory, that is jazz guitar reharmonization techniques using Malay Asli song, subgenre Malay traditional music. Although this article is based on the music education field, we believe pragmatism principles can be utilizing to bridging the gaps of connecting western music elements into traditional music practices.

\section{Pragmatism}

There are three prominent names in the tenet of pragmatism movement, Charles Sanders Pierce, William James and John Dewey (Agarwarl, 2010; Farjoun et al., 2015; Nowell, 2015; Russill, 2016; Adeleye; 2017). Pragmatic terminology came from Greek vocabulary, meaning action, the other word for it, practice or practical that came from the word pragmatikos (Farjoun, 2015; Adeleye, 2017). Pragmatic define a practical and flexible way of solving a problem (Farjoun et al, 2015). While, praxis and pragmatism shared the same meaning as praxis indicate human action, while pragmatism refers as tangible action (Regelski, 2017). Studies by Plowright (2016) explained Charles Sanders Pierce believes that definitions just the beginning of understanding an idea. Therefore, he has developed a method of higher-order thinking to explained that understanding, which Peirce views as pragmatism.

\section{Principles of Pragmatism}

According to pragmatism, whatever is practical and works, that is the truth. It is not right or wrong on the ideas themselves, they are true if the ideas employed can solve a problem related to educational practice (Bhatt, 2018). Moreover, similar studies have been done on pragmatism, they believe that reality is not in one perception, but can be seen in multidimensional. Whatever works also can change, because of reality change. Thus, no one can claim what they believed in possess any ultimate truth (Sharma et al, 2018). Thus, pragmatism views 'reality', 'goodness' or 'badness' and 'truth' in the same relative terms, that is why pragmatism is also known as experimentalism, because an experiment is the only criterion to gain the truth (Adeleye, 2017). Reality is something that we believed, linked by our past experiences that influenced our action and thinking. Charles Sanders Peirce suggested to view belief as a way of thinking and habit as a rule of action or a rule for action (Plowright, 2016). Other studies done by Sharma et al (2018), proposed that there are 7 principles in viewing pragmatism:

1. Pluralism: There are numerous of reality, not just one because each person holding a truth according to what they experience in the past.

2. Emphasis on Change: The world is a constant flux, evolving and progressing to attain the truth.

3. Emphasis on Social Aspects: Education is to develop social personality so that student can excel in society while developing their social circumstances.

4. Utilitarianism: To fulfil our purposes and to test the truth of our action with reality.

5. Changing Aim and Values: Old values and aim cannot be the truth as situation and condition are changing from time to time.

6. Individualism: Adjust according to our environment, equally with common interest and liberty.

7. Experimentalism: Emphasise the importance of action rather than mere ideas.

\section{Issues}

Applying music theory such as chords, scales or even to craft an improvisation required both understandings in the music-theoretical and 
practical aspect of chosen music instrument. Practice and theory are unified, even though these ideas it is not recognizable among practitioners (Regelski $\&$ Gates, 2009). Needless to say, in our case, we choose pragmatism because of the praxis concept that this theoretical paradigm offers. Learning music theory can help to appreciate music in much wider aspects, but without applying on music instrument, we only grasp theoretically the idea of music theory but not practically. Education in music comprises the process of learning musical knowledge and developing music theory into practices, combining both musicality and technicality aspects of the instrument. To back up our argument, we compare a few proponents of theoretical in this article. The reason we choose pragmatism because we do not view knowledge as an object, as Wilson (2010) described:

"...if your epistemological stance is a positivist one, then you are likely to view knowledge as an object or in other words, it exists independently of the mind."

(page 19)

If we seized above statement and look into music learning, students can represent as an object, in contradiction of pragmatism, where each individual highlighted and they are treated as a social agent that shapes the environment by their actions (Farjoun et al, 2015). In addition, compared to positivism, pragmatist believes that knowledge itself does not exist independently from the mind, it is an artefact that we adjusted through locating and solving problems within our environment (Bhatt, 2018). Correspondingly, pragmatism dissatisfied by the usefulness of practical that presented within realism and idealism ideas. Ideas itself does not indicate true or false if they can be implemented to resolved a problem associated in educational practices, that ideas which pragmatism believe what works will be the truth because the foundation of pragmatism relies on practical significances (Bhatt, 2018). In the other hand, realism epistemology understandings an idea is true if it synchronizing with the reality it represents because our mind does not generate the world but we replicate from it (Bhatt, 2018). If we stand using realism paradigm in learning music, students might not understand music explicitly, especially in learning jazz guitar reharmonization technique, because with reharmonization, any type of chord tones can be treated either root, third, fifth, seventh or even as tension notes of any chords. Additionally, in the perspective of learning traditional music, students being taught with the same old repertoires that replicated over the time by their conservative mindset of traditional music teachers, because they do not agree on assimilate western music elements in teaching and learning traditional music.

From the basic understanding of idealism, the emphasis on mental activity that constructs reality as a whole (Bhatt, 2018). Viewing idealism in the context of music, ideas and internalization itself is not adequate to understand music holistically, without applying musical knowledge practically. Bhatt argues that idealist school of thoughts do not believe external reality, outside than what they believe in, for them, self-knowing is the ultimate truth. This happens in music education, either in learning modern or traditional music, where the learning process transmitted using oral tradition and upholding with strong believe that traditional music should be maintained and preserve as it. Consequently, aligning idealism paradigm in this sense also does not seem to encourage interculturalism among music students and instrumental teachers to creatively incorporate jazz guitar reharmonization techniques within the outer range of western music repertoires, other than using jazz standards to learn musical information. In a similar manner, if we hinge only on self-knowing of current tradition music practitioner that is not willing to assimilating western musical elements upon delivering traditional music to students, the continuum of old traditional learning approaches will continue. Then, 
we cannot extend the learning of jazz guitar reharmonization techniques using Malay Asli song repertoires.

\section{Utilizing Pragmatism Approach in Learning Jazz Guitar Reharmonization Techniques}

Pragmatism believes that old and conservative education is irrelevant and lifeless (Sharma et al, 2018). To preserve tradition, we should explore and assimilate western music elements merged into traditional music. In doing so, based on pragmatism principle highlighted by Sharma et al (2018) mentioned above, we incorporate those seven principles in relation to learning reharmonization technique. First, pragmatism emphasized pluralism. The truth is not one but many, same goes with chords, by utilizing reharmonization technique, a note can transform into various types of chord, either major to minor, dominant to minor and so forth. Semiotically, reharmonization is like painting an old car with new colours, providing new fresh colours by modifying the harmonic progression (Felts, 2002). Broadly speaking, reharmonization or concept of jazz transformations has been widely associated with jazz theory (Terefenko, 2009). But this does not get much attention among traditional music practitioners. Next points, we combined both pragmatism principle, emphasis in change and changing on values and aims. Because we cannot just accept the old values and aim, as it is. The world itself keeps changing from time to time, but this does not occur in traditional music practices. Even though the reharmonization technique synonym within jazz music, we argue that the reharmonization technique can also complement into traditional music, by substitute the old chords with a new one, rearrange the melodies into chord melody style. Thirdly, the concept of utilitarianism in pragmatic is to examine the truth and reality, and critically examine what useful to fulfil our purposes. As mentioned early on, reharmonization is a process of substituting a single note or chord to a new type of chord. For instance, a single note $\mathrm{C}$ can nicely fit in $\mathrm{C}^{\mathrm{maj} 7}, \mathrm{~A}^{\min 7}, \mathrm{~F}^{\mathrm{maj} 7}, \mathrm{~F} \#^{\min 7 b 5}$, $A b^{7}$ and many more. With all these choices of chords, is it not impossible to apply reharmonization techniques in the context of traditional music, because pragmatists believe in freedom, mutual interests and equality.

Reharmonization technique can offer freedom as we can choose what type of chord we want to use, either major $7^{\text {th }}$, minor $7^{\text {th }}, \quad$ dominant $7^{\text {th }}, \quad$ minor $7 b 5$, diminished $7^{\text {th }}$ or even augmented $7^{\text {th }}$. There are many types of a chord can be chosen, as students can freely adjust within their musical preferences. Lastly, the social aspect and experimentalism principle of pragmatism can relate to merging reharmonization technique with Malay Asli song. The aim of education is to help developing student's social personality. But if we just focus on one type of music, how can music social interaction happen if we don't openly accept music as a whole, without prejudice on western or traditional music. Socialization occurs in the music itself, but not in the case of learning traditional music where students learnt as to what been played by their teachers or traditional ensemble tutor. Even learning in jazz guitar also encounters the same situation, focusing on jazz standards repertoires. Lastly, pragmatism is an experimentalist, because of pragmatists emphasis action more than just idea. By experimenting, we could justify either our idea work or not. Educative process occurs when we start exploring. In our case, we can experiment Malay Asli song with reharmonizing the current chord from major to minor, and much more. Summarizing our sentences, by experimenting, students not just exploring new musical ideas, they also realized that reharmonization is not just fit for the western type of music. Thus, reharmonization techniques can be applied both in performance and arranging for another type of instruments. Both instrumental teachers and students need to add experimental values and ready for experimenting in both traditional and western music. 


\section{CONCLUSION}

We explored how pragmatism can occasionally reform, complement traditional music using reharmonization techniques. Pragmatism offers opportunities for music educators to revised values in instrumental lesson since pragmatism paradigm being utilitarian and practical (Sharma et al, 2018). The flexibilities in this paradigm can widen our perceptions on the usage of reharmonization techniques, weather in western or traditional music, breaking us from ignorance and false belief that westernization only leads to destroying traditional music authenticity. Rather than competency views and ways of thinking, Bhatt (2018) suggest that philosophy is useful in education because we can examine our rationality on educational ideas with another ideal's consistency. Education is dynamic and it will keep evolving, chances to preserve traditional heritage can continue with mixing both western and traditional music, producing new form and style of Malay Asli Music (Hashim, 2010), because pragmatism facilitates theory and practical. If we don't put credit on a new style of Malay Asli music, ironically, this music will only continue to stay within the older generation old. Any practices from different music genre surely share similarities of musical elements such as harmony. Each different practice in music can closely be linked together with other music if broaden up musical knowledge into different perspective as our paper organizes and extends pragmatism principles, bringing together jazz guitar reharmonization technique and Malay Asli song, carrying the legacy of traditional music repertoires in a new and different path of learning jazz harmony theory.

\section{REFERENCE}

Adeleye, J. O. (2017). Pragmatism and Its Implications On Teaching And Learning In Nigerian Schools. Research Highlights in Education and Science 2017, 2. URL: https://www.isres.org/books/Resear
ch_Highlights_in_Education_and_Sc ience_2017_21-12-2017.pdf\#page $=6$

Abdullah, M. H. (2004). Musical Culture of Malaysia. Universiti Pendidikan Sultan Idris.

Ahmed, I. Kechot, A. S. (2015). Lagu Melayu Asli: Unsur Sinkretisme Dalam Instrumentasi Persembahan. Jurnal Melayu. 14(2). 307-327. URL: http://ejournals.ukm.my/jmelayu/a rticle/download/11451/3712

Ahmad, I. (2004). Muzik Kontemporari sebagai Alat Pembentukan Nilai dalam Komuniti: Ke Mana Halatuju Kita?. URL:

http://repo.uum.edu.my/1853/

Agarwal, S. Bansal, S. \& Maheshwari, V. K. (2010). Pragmatism and education. URL: https://www.scribd.com/doc/30853 941/Pragmatism-and-Education.

Arshad, S. F. (2015). Manual asas permainan lagu Melayu asli secara instrumental. Masters thesis. Akademi Seni Budaya dan Warisan Kebangsaan, Kuala Lumpur.

Bhatt, S. R. (2018). Philosophical Foundations of Education. In Philosophical Foundations of Education. Springer. 17-23. URL: http://www.ifeet.org/files/Philosop hical-Foundation-of-education.pdf

Cain, M. (2015). Celebrating musical diversity: Training culturally responsive music educators in multiracial Singapore. International Journal of Music Education, 33(4), 463-475.

Elkjaer, B, \& Buch, A. (2015). Pragmatism and Practice Theory: Convergences or collisions. In Organizational Learning and 
Knowledge Capabilities. URL: https://pure.au.dk/ws/files/982261 99/OLKC_2015_buch_elkjaer_fini.p df

Farjoun, M, Ansell, C, \& Boin, A. (2015). PERSPECTIVE-Pragmatism in organization studies: Meeting the challenges of a dynamic and complex world. Organization Science, 26(6), 1787-1804.

DOI:

10.1287/orsc. 2015.1016

Felts, R. (2002). Reharmonization Techniques. Arranging: Reharmonization. Boston. MA: Berklee Press.

Hashim, M. N. (2012). Variation of Malay Asli Music There is no 'Right or Wrong'. Essays on Issues in Music and its Function. UM book Series on Research in Musicology 4. 1-17. URL:

https://www.researchgate.net/profil e/Zaharul_Saidon2/publication/294 088667_Developing_Malaysian_Hig h_School_Marching_Bands_Issues_ Challenges_and_Strategies/links $/ 56 \mathrm{~b}$ df22e08ae44da37f88393.pdf \#page $=1$ 6

Low, E. K. (2014). A Study of Jazz Piano Pedagogy in Malaysia and Taiwan. Master Thesis. The National Taichung University of Education. URL:

https://pdfs.semanticscholar.org/4e 39/91f1117ae6d06fe32003d6bafd40f 3f8da9d.pdf

Nowell, L. (2015). Pragmatism and integrated knowledge translation: exploring the compatabilities and tensions. Nursing Open, 2(3), 141148. DOI: $10.1002 /$ nop 2.30

Plowright, D. (2016). Charles Sanders Peirce: Pragmatism and education. Springer Netherlands.
Regelski, T. A. (2017). Pragmatism, Praxis, and Naturalism: The Importance for Music Education of Intentionality and Consummatory Experience in Musical Praxes. Action, Criticism \& Theory for Music Education, 16(2). 102-143.

Regelski, T. A., \& Gates, J. T. (2009). Music education for changing times: Guiding visions for practice (Vol. 7). Springer Science \& Business Media. DOI: 10.1007/978-90-481-2700-9

Ritawati, T. (2017). The Original of Malay Songs (OMS) as the Symbolism of Malay Cultural Heritage. International Journal of Social Sciences. 67-72.

Russill, C. (2016). Pragmatism. The International Encyclopedia of Communication Theory and Philosophy, 1-13. DOI: 10.1002/9781118766804.wbiect176

Sharma, S, Devi, R, \& Kumari, J. (2018). Pragmatism in Education. International Journal of Engineering Technology Science and Research. 5(1). 1549$1554 . \quad$ URL: http://www.ijetsr.com/images/short _pdf/1517753191_1549-1554oitm828-ijetsr.pdf

Shah, S. M. (2013). Contextualizing the transmission of Malaysian traditional music. Procedia-Social and Behavioral Sciences, 93, 1000-1004. DOI: https://doi.org/10.1016/i.sbspro.201 $\underline{3.09 .318}$

Spies, B. (2015). Introducing music students to harmony-an alternative method. Education as Change, 19(1), 165-187. DOI:

$10.1080 / 16823206.2014 .943258$

Spitzer, P. (2015). Jazz theory handbook. Mel Bay Publications. URL: 
http://www.jazzstandards.com/theo ry/harmony-and-form.htm (Diakses pada 4 April, 2017).

Terefenko, D. (2009). Jazz Transformations of the ii7-V7-I Progression. URL: https://www.crj-online.org/v1/CRJJazzTransformations.php

Wilson, J. (2010). Essentials of Business Research: A Guide to Doing Your Research Project. SAGE Publications 